(submitted, Hazardous Waste and Hazardous Materials, June, 1997)

\title{
Thermal Decomposition Studies of Halogenated Organic Compounds
}

RECEIVED

by

\section{JUN 20 P97}
Q 8.TI J.V. Michael and S. S. Kumaran\#
Chemical Dynamics Group

Chemistry Division, Argonne National Laboratory, Argonne, IL 60439

Submitted to the Fifth International Congress

on Toxic Combustion Byproducts,

June 25-27, 1997

University of Dayton, Dayton, Ohio

\begin{abstract}
The submitted manuscript has been created by the University of Chicago as Operator of Argonne National
Laboratory ("Argonne") under Contract No. W-31-109-ENG-38 with the U.S. Department of Energy. The U.S.

Government retains for itself, and others acting on its behalf, a paid-up, nonexclusive, irrevocable worldwide

license in said article to reproduce, prepare derivative works, distribute copies to the public, and perform publicly

and display publicly, by or on behalf of the Government.
\end{abstract}

\#Present address: Cabot Corporation, 700 E. US Highway 36, Tuscola, IL 61953.

This work was supported by the U.S. Department of Energy, Office of Basic Energy Sciences, Division of Chemical Sciences, under Contract Nos.W-31-109-Eng-38

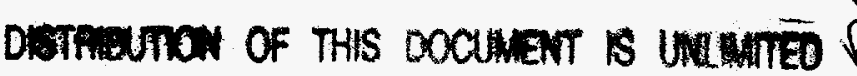




\section{DISCLAIMER}

This report was prepared as an account of work sponsored by an agency of the United States Government. Neither the United States Government nor any agency thereof, nor any of their employees, make any warranty, express or implied, or assumes any legal liability or responsibility for the accuracy, completeness, or usefulness of any information, apparatus, product, or process disclosed, or represents that its use would not infringe privately owned rights. Reference herein to any specific commercial product, process, or service by trade name, trademark, manufacturer, or otherwise does not necessarily constitute or imply its endorsement, recommendation, or favoring by the United States Government or any agency thereof. The views and opinions of authors expressed herein do not necessarily state or reflect those of the United States Government or any agency thereof. 


\section{DISCLAMIER}

Portions of this document may be illegible in electronic image products. Images are produced from the best available original docoment. 


\begin{abstract}
Thermal decomposition results for $\mathrm{CCl}_{4}, \mathrm{CHCl}_{3}, \mathrm{CH}_{2} \mathrm{Cl}_{2}, \mathrm{CH}_{3} \mathrm{Cl}, \mathrm{C}_{3} \mathrm{H}_{3} \mathrm{Cl}, \mathrm{CFCl}_{3}, \mathrm{CF}_{2} \mathrm{Cl}_{2}$, $\mathrm{CF}_{3} \mathrm{Cl}, \mathrm{CF}_{2} \mathrm{HCl}, \mathrm{CF}_{3} \mathrm{I}, \mathrm{CH}_{3} \mathrm{I}, \mathrm{C}_{2} \mathrm{H}_{5} \mathrm{I}, \mathrm{C}_{6} \mathrm{H}_{5} \mathrm{I}$, and $\mathrm{CCl}_{2} \mathrm{O}$ are presented. The results were obtained by shock tube techniques coupled with optical spectroscopic detection of transient species formed from dissociation. The method is illustrated with the $\mathrm{CH}_{3} \mathrm{I}(+\mathrm{Kr}) \rightarrow \mathrm{CH}_{3}+\mathrm{I}(+\mathrm{Kr})$ reaction where decomposition was monitored using I-atomic resonance absorption spectrometry (ARAS). Modern unimolecular rate theoretical analysis has been carried out on the present cases, and the conclusions from these calculations are discussed. Lastly, the possible destruction of halo-organics by incineration is considered and some implications are discussed.
\end{abstract}

\title{
INTRODUCTION
}

Halogen containing molecules have been extensively used in industrial applications for decades. Some (e. g., the chlorofluoromethanes) have been used as propellants, solvents, and refrigerants simply because they are chemically inert whereas others are not. Anthropogenic release of halo-organics into the environment can cause major undesirable effects in a variety of ways whether it be release of carcinogenic agents or molecules capable of depleting stratospheric ozone. As one strategy for solving environmental problems, the production of these molecules has been drastically reduced. For example, starting in 1996, production of chlorofluoromethanes ceased in developed countries except for special needs [1].

The destruction of pre-existing amounts of halo-organics can then present other serious environmental problems. Incineration has been suggested as a destruction strategy, but if this is to be considered, then a complete engineering design, with accurate predictions of organic emissions [2-5], requires a full knowledge of the elementary chemical decomposition and oxidation mechanisms for these molecules. Even though most high temperature chemical mechanisms include processes of the general type, stable molecule $+\mathrm{O}_{2} \rightarrow$ radical products, there is really no compelling reason to believe that such processes are ever fast enough to be a major destruction pathway. In combustion systems where the atom and radical concentrations can be $\sim 10^{16}$ molecules $\mathrm{cm}^{-3}$, abstraction of $\mathrm{H}$-atoms can contribute to destruction provided the molecule contains one or more hydrogens and the rate constant is $\sim 10^{-13} \mathrm{~cm}^{3}$ molecule-1 $\mathrm{s}^{-1}$. Rate constants of this magnitude typically require that the temperature be $\sim 1300-1500 \mathrm{~K}$. However, at these temperatures, direct unimolecular decomposition of haloorganics is almost always the preferred destruction pathway since $\mathrm{C}-\mathrm{Cl}, \mathrm{C}-\mathrm{Br}$, and $\mathrm{C}-\mathrm{I}$ bond 
strengths are much less than those for $\mathrm{C}-\mathrm{F}$ or $\mathrm{C}-\mathrm{H}$. In this view, overall destruction will then involve subsequent radical $+\mathrm{O}_{2}$ reactions after radical formation from direct unimolecular decomposition. This realization supplies the main motivation for the present study.

In previous work from this laboratory, the thermal decomposition studies have been carried out with a shock tube apparatus utilizing atomic resonance absorption spectrometry (ARAS) as the detection technique. In this paper, we will review the experimental methods used to obtain data for selected halo-organics. We then review results for fourteen molecules, and these results will be discussed in terms of modern unimolecular rate theory.

\section{EXPERIMENTAL}

The experimental apparatus, techniques, and the associated electronics used in the present study have been completely described elsewhere [6,7]. Therefore only a few comments are necessary that are pertinent to the present study. Figure 1 is a schematic diagram of the shock tube equipment used here. It consists of a driver chamber and a 7-m 304 stainless steel tube (i. d. $9.74 \mathrm{~cm}$ ) section,

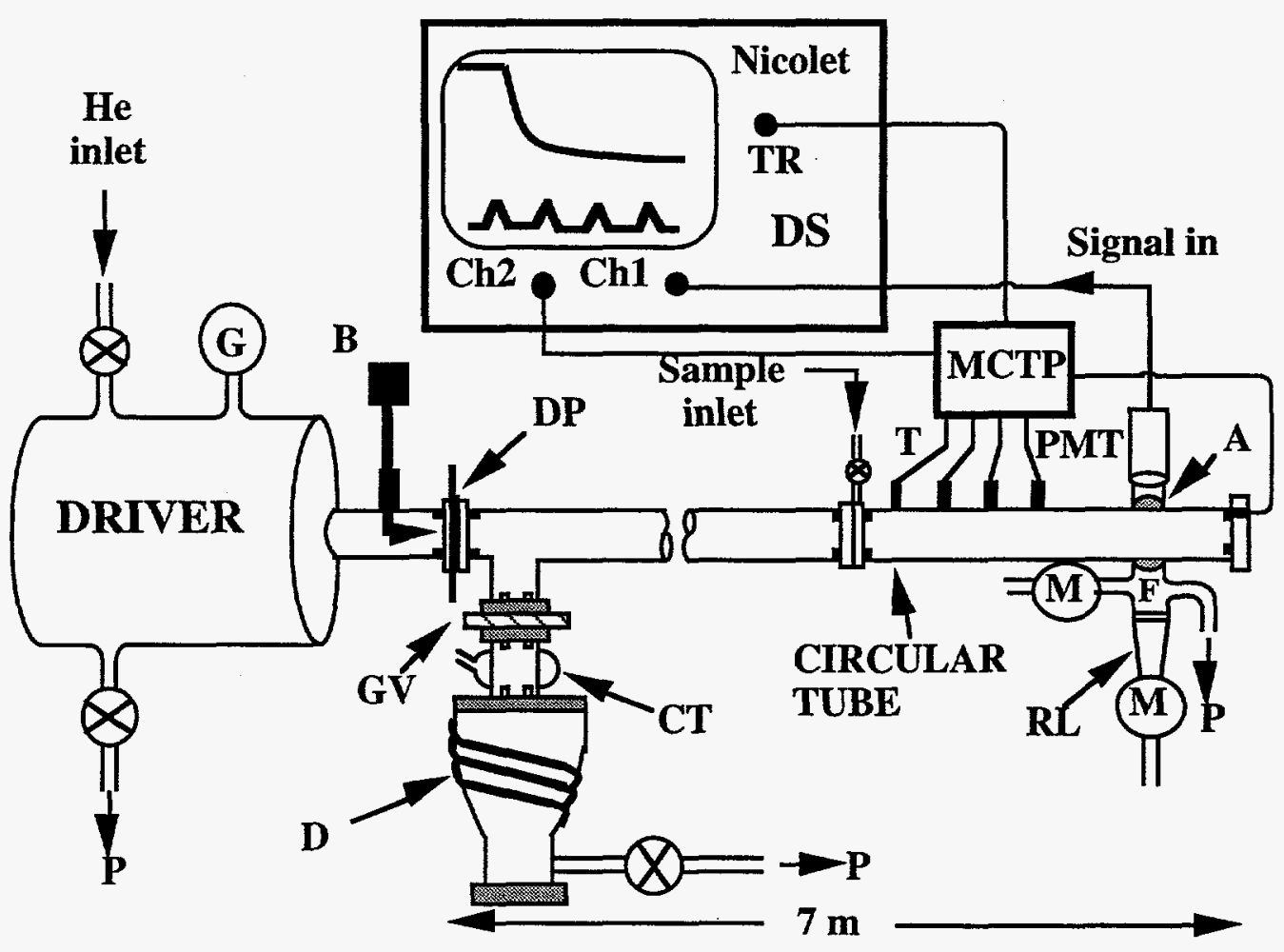

FIGURE 1. Schematic diagram of the apparatus. P-rotary pump. D-oil diffusion pump. CT-liquid nitrogen baffle. GV-gate valve. G-bourdon gauge. B-breaker. DP-diaphragm. T-pressure transducers. $M$ microwave power supply. F-atomic filter. RLresonance lamp. A-gas and crystal window filter. PMT-photomultiplier. DS-digital oscilloscope. MCTP-multiple channel trigger processor. TR-trigger pulse. 
the inside surface of which has been polished to be quite passive. A rounded square end-piece can also be inserted in place of the tube for certain applications The driver and driven sections are separated by a thin aluminum diaphragm ( 4 mil, unscored $1100-\mathrm{H} 18$ ). This is mounted between vacuum flanges that are attached to the ends of the driver and driven sections. The tube is routinely pumped by an Edwards Vacuum Products Model CR100 P fore-pump diffusion-pump combination to $<10^{-8}$ Torr before loading the test gas mixture. Reaction mixtures are prepared manometrically with an MKS Baratron capacitance manometer. Initial reactant loading pressures are measured with the same manometer. Experiments for thirteen of the fourteen molecules were performed behind reflected shock waves, the exception being $\mathrm{CCl}_{2} \mathrm{O}$ where incident shock wave techniques were used. The average incident shock velocity for each experiment was measured with fast piezoelectric transducers (PCB Piezotronics, Inc., Model 1132 A) at eight different stations that are equally spaced well downstream from the diaphragm. Both incident and reflected shock regime thermodynamic properties were calculated from velocities with appropriate Mirels' boundary layer corrections as described earlier $[6,8,9]$.

ARAS techniques for detecting $\mathrm{Cl}-[10,11]$ and I-atom [12] concentrations have been used for most of the studies. However, in one study [13], multi-pass optical absorption of $\mathrm{CF}_{2}$, with White cell optics [14], was used as the detection method. In all experiments, the photometer system was radially located $6 \mathrm{~cm}$ from the end plate, and the optical path length was either 9.94 or $8.745 \mathrm{~cm}$ depending on whether a round or square shock tube was used for a particular investigation. Optical transmittances from resonance lamps were measured with photomultiplier tubes, and the signals were processed using a Nicolet $4094 \mathrm{C}$ digital oscilloscope.

For all the studies, the He driver gas (99.995\%) was obtained from Air Products and Chemicals, Inc. Diluent Ar and $\mathrm{Kr}$ used in the reaction mixtures was Scientific grade (99.9995 and $99.997 \%$, respectively) from MG Industries. All other gases were either ultra-high purity or research grade. The halo-organic molecules were usually obtained as technical grade ( $99 \%)$, and therefore, these were always purified by bulb-to-bulb distillation. The middle thirds were retained for mixture preparation.

\section{RESULTS AND DISCUSSION}

We have completed studies on the thermal dissociations: $\mathrm{CCl}_{4}[15,16], \mathrm{CHCl}_{3}$ [17], $\mathrm{CH}_{2} \mathrm{Cl}_{2}$ [18], $\mathrm{CH}_{3} \mathrm{Cl}[10,11], \mathrm{C}_{3} \mathrm{H}_{3} \mathrm{Cl}[19], \mathrm{CFCl}_{3}$ [16,20], $\mathrm{CF}_{2} \mathrm{Cl}_{2}$ [16,21], $\mathrm{CF}_{3} \mathrm{Cl}[16,22], \mathrm{CF}_{2} \mathrm{HCl}[13]$, $\mathrm{CF}_{3} \mathrm{I}$ [12], $\mathrm{CH}_{3} \mathrm{I}$ [23], $\mathrm{C}_{2} \mathrm{H}_{5} \mathrm{I}$ [24], $\mathrm{C}_{6} \mathrm{H}_{5} \mathrm{I}$ [25], and $\mathrm{CCl}_{2} \mathrm{O}$ [26]. The methods used are nearly identical in all cases, and for the purposes of discussion, we will illustrate the method with $\mathrm{CH}_{3} \mathrm{I}$ data [23].

Using I-atom ARAS detection, the temporal absorbance, $(\mathrm{ABS})_{\mathrm{t}} \equiv-\ln \left(I_{t} / I_{0}\right)\left(I_{t}\right.$ and $I_{0}$ refer to transmitted and incident I-atom resonance light intensities, respectively), is measured as $\mathrm{CH}_{3} \mathrm{I}$ decomposes. It is often necessary to pre-determine the curve-of-growth for the transient species in order to convert $(\mathrm{ABS})_{\mathrm{t}}$ into absolute concentration. The reason this is desirable is that it then allows for yield determinations (i. e.; the number of species formed for every molecule decomposed). Figure 2 shows the I-atom curve-of-growth, determined using the $\mathrm{CF}_{3} \mathrm{I}$ decomposition [12].

With Fig. 2, (ABS) $)_{t}$ measured in the $\mathrm{CH}_{3} \mathrm{I}$ decomposition can be converted to an absolute Iatom concentration profile; i. e., a plot of $[1]_{t}$ against time. Fig. 3 shows a typical raw data result (top panel) along with the profile derived from it (bottom panel). Note that at long times [I] becomes constant indicating that $\mathrm{CH}_{3} \mathrm{I}$ has completely dissociated. The ratio, $[\mathrm{I}]_{\infty} /\left[\mathrm{CH}_{3} \mathrm{I}\right]_{0}$, is the yield, and in this case, we found a yield of $(1.04 \pm 0.09)$ for $1238 \leq \mathrm{T} \leq 1820 \mathrm{~K}$ [23]. This shows unambiguously that $\mathrm{CH}_{3}+\mathrm{I}$ is the only important pathway and that singlet methylene and $\mathrm{HI}$ (molecular elimination) is not significant. This result also indicates that I-atoms are produced by a first-order process and that simple first-order analysis can be used to obtain the unimolecular rate constant from the rate law,

$$
\ln \left\{[\mathrm{I}]_{\infty}-[\mathrm{I}]_{0} /[\mathrm{I}]_{\infty}\right\}=-\mathrm{k}_{1 \mathrm{st}} \mathrm{t}
$$


The experiment shown in Fig. 3 is analyzed using eqn. (1), and the result is plotted in Fig. 4. The negative slope gives the unimolecular rate constant. We found that the first-order rate constants were dependent on total pressure, and therefore, the final results are presented as second-order in Arrhenius plots as shown in Fig. 5.

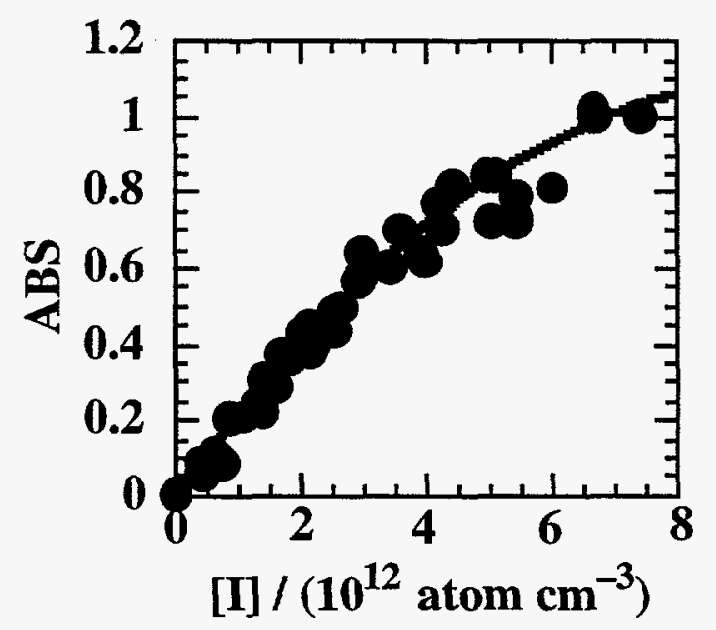

FIGURE 2. I-atom curve-of-growth determined from the complete dissociation of $\mathrm{CF}_{3} \mathrm{I}$.
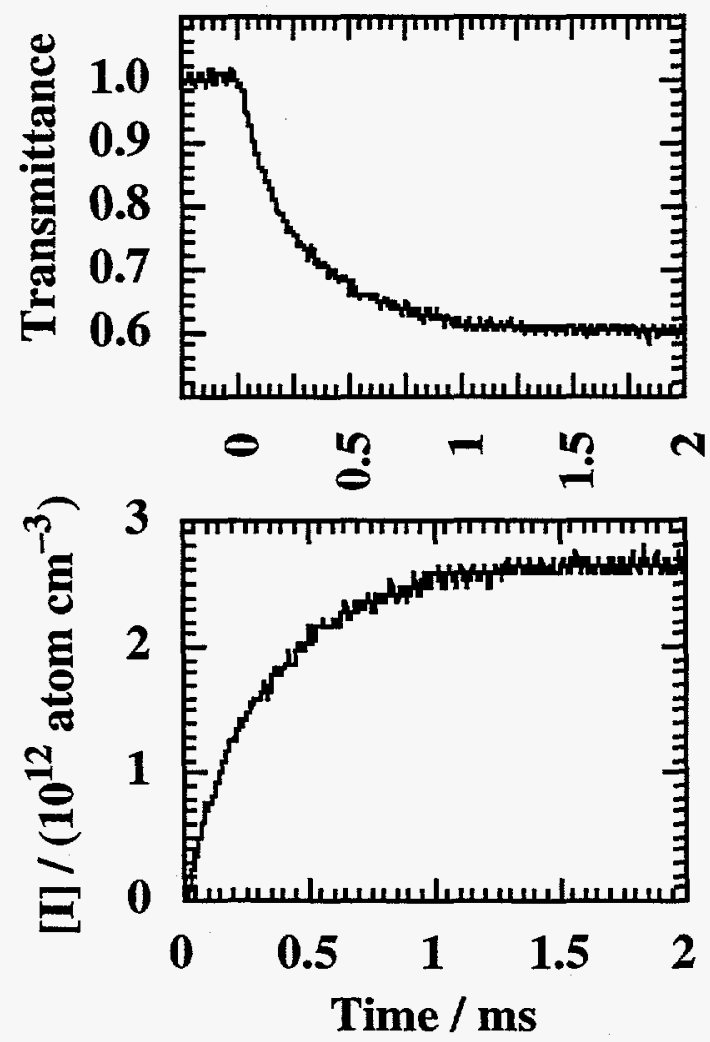

FIGURE 3. Top: Experimental record of $(\mathrm{ABS})_{\mathrm{t}}$ against time 
for $\mathrm{CH}_{3} \mathrm{I}$. Bottom: Derived I-atom profile. $\mathrm{T}=$ $1348 \mathrm{~K}$, density $=1.918 \times 10^{18} \mathrm{~cm}^{-3}$, and $\left[\mathrm{CH}_{3} \mathrm{I}\right]_{0}$ $=2.451 \times 10^{12} \mathrm{~cm}^{-3}$.

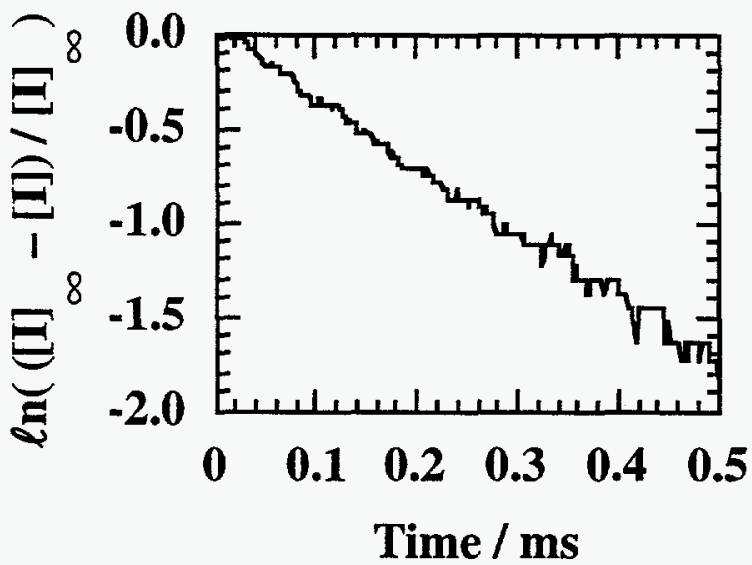

FIGURE 4. A semi-log plot based on eqn. (1) for the experiment shown in Fig. 3. The negative slope gives the firstorder rate constant for the conditions of Fig. 3.

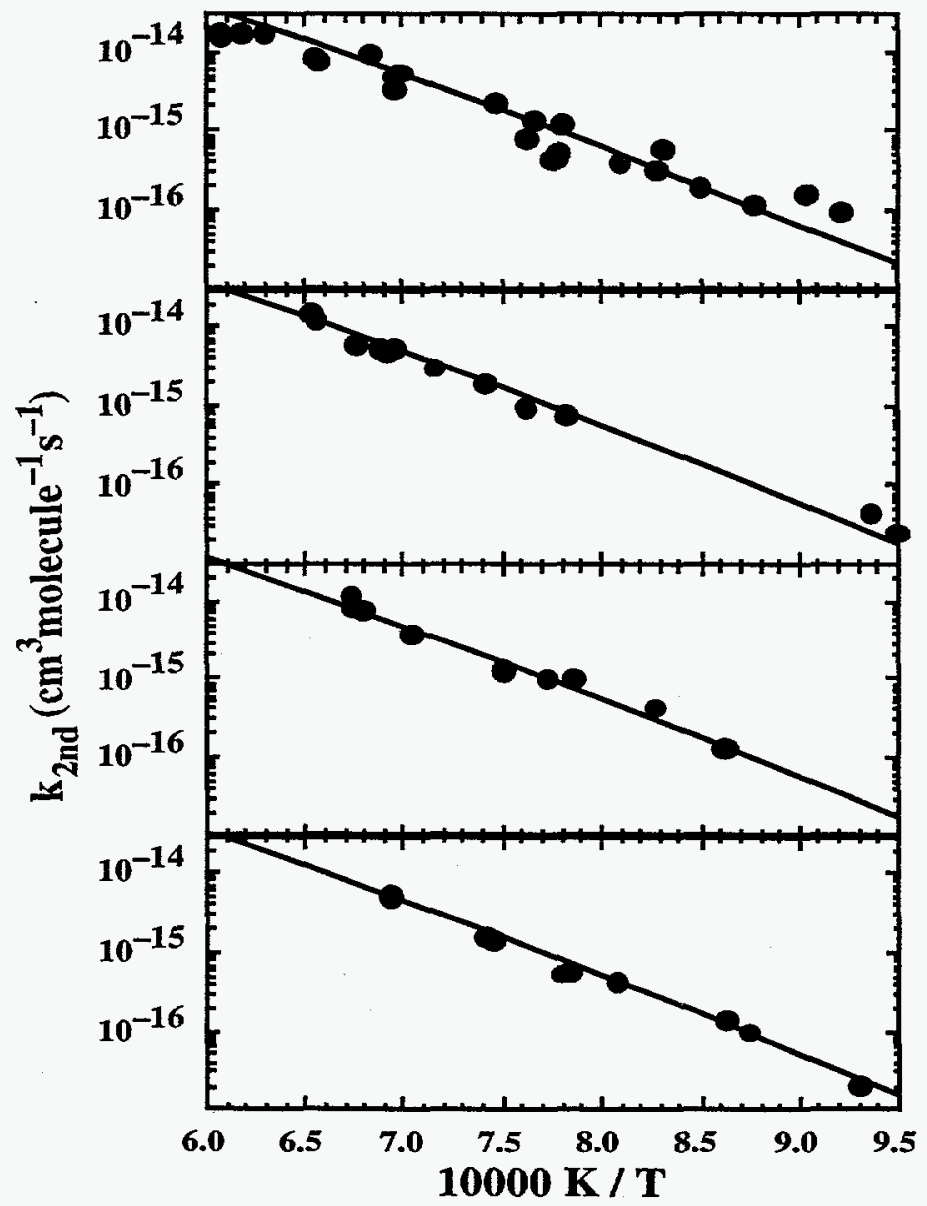


FIGURE 5. Decomposition results for $\mathrm{CH}_{3} \mathrm{I}$ at different densities.

We have used either I- and Cl-atom ARAS detection to determine rate constants in twelve of the fourteen studies. Kiefer and co-workers, who use the Laser Schlieren (LS) technique [27], have supplied additional data, and these collaborations have generally increased the T-range over which a particular reaction has been studied. In all cases, Arrhenius expressions, that do not include density effects, have been reported, and these are summarized in Table 1. These expressions can be used in

TABLE 1.

Experimental Rate Constants for the Thermal Decomposition of Halo-Organic Molecules.

\begin{tabular}{lcccc}
\hline \hline Reactions & A & B & T-range(K) & Ref. \\
\hline & & & & \\
(1) $\mathrm{CCl}_{4} \rightarrow \mathrm{Cl}+\mathrm{CCl}_{3}$ & $1.91 \times 10^{-8}$ & 22038 & $1470-2200$ & $15,16^{\mathrm{a}}$ \\
& $4.27 \times 10^{-8}$ & 23528 & $1100-1700$ & \\
(2) $\mathrm{CHCl}_{3} \rightarrow \mathrm{HCl}+\mathrm{CCl}_{2}$ & $7.07 \times 10^{-8}$ & 22516 & $1282-1878$ & $17^{\mathrm{a}}$ \\
(3a) $\mathrm{CH}_{2} \mathrm{Cl} \rightarrow \mathrm{Cl}+\mathrm{CH}_{2} \mathrm{Cl}$ & $6.64 \times 10^{-9}$ & 28404 & $1400-2300$ & $18^{\mathrm{a}}$ \\
(3b) $\mathrm{CH}_{2} \mathrm{Cl} \rightarrow \mathrm{HCl}+\mathrm{CHCl}_{2}$ & $2.26 \times 10^{-8}$ & 29007 & $1400-2300$ & \\
(4) $\mathrm{CH}_{3} \mathrm{Cl} \rightarrow \mathrm{Cl}+\mathrm{CH}_{3}$ & $1.09 \times 10^{-8}$ & 29325 & $1663-2059$ & $10,11^{\mathrm{a}}$ \\
(5a) $\mathrm{C}_{3} \mathrm{H}_{3} \mathrm{Cl} \rightarrow \mathrm{C} \mathrm{H}_{3}+\mathrm{Cl}$ & $2.07 \times 10^{9}$ & 19144 & $1200-1700$ & $19^{\mathrm{b}}$ \\
(5b) $\mathrm{C}_{3} \mathrm{H}_{3} \mathrm{Cl} \rightarrow \mathrm{HCl}+\mathrm{c}-\mathrm{C}_{3} \mathrm{H}_{2}$ & $6.79 \times 10^{7}$ & 14141 & $1200-1700$ & \\
(6) $\mathrm{CFCl}_{3} \rightarrow \mathrm{Cl}+\mathrm{CFCl}_{2}$ & $2.82 \times 10^{-8}$ & 26420 & $1275-1950$ & $16,20^{\mathrm{a}}$ \\
(7) $\mathrm{CF}_{2} \mathrm{Cl} \rightarrow \mathrm{Cl}+\mathrm{CF}_{2} \mathrm{Cl}$ & $1.34 \times 10^{-7}$ & 31663 & $1446-2090$ & $16,21^{\mathrm{a}}$ \\
(8) $\mathrm{CF}_{3} \mathrm{Cl} \rightarrow \mathrm{Cl}+\mathrm{CF}_{3}$ & $1.73 \times 10^{-7}$ & 33837 & $1521-2173$ & $16,22^{\mathrm{a}}$ \\
& $1.15 \times 10^{-8}$ & 28330 & $1800-3000$ & \\
(9) $\mathrm{CF}_{2} \mathrm{HCl} \rightarrow \mathrm{CF}_{2}+\mathrm{HCl}$ & $2.42 \times 10^{-9}$ & 20180 & $1047-1731$ & $13^{\mathrm{a}}$ \\
(10) $\mathrm{CF}_{3} \mathrm{I} \rightarrow \mathrm{I}+\mathrm{CF}_{3}$ & $3.24 \times 10^{-9}$ & 17286 & $1033-1285$ & $12^{\mathrm{a}}$ \\
(11) $\mathrm{CH}_{3} \mathrm{I} \rightarrow \mathrm{I}+\mathrm{CH}_{3}$ & $4.36 \times 10^{-9}$ & 19858 & $1052-1616$ & $23^{\mathrm{a}}$ \\
(12a) $\mathrm{C}_{2} \mathrm{H}_{5} \mathrm{I} \rightarrow \mathrm{I}+\mathrm{C}_{2} \mathrm{H}_{5}$ & $6.34 \times 10^{9}$ & 15894 & $946-1303$ & $24 \mathrm{~b}$ \\
(12b) $\mathrm{C}_{2} \mathrm{H}_{5} \mathrm{I} \rightarrow \mathrm{HI}+\mathrm{C}_{2} \mathrm{H}_{4}$ & $9.51 \times 10^{8}$ & 15894 & $946-1303$ & \\
(13) $\mathrm{C}_{6} \mathrm{H}_{5} \mathrm{I} \rightarrow \mathrm{I}+\mathrm{C}_{6} \mathrm{H}_{5}$ & $1.98 \times 10^{11}$ & 23120 & $1082-1416$ & $25^{\mathrm{b}}$ \\
(14a) $\mathrm{CCl}_{2} \mathrm{O} \rightarrow \mathrm{Cl}+\mathrm{COCl}$ & $7.24 \times 10^{-8}$ & 30549 & $1400-2000$ & $11,26^{\mathrm{a}}$ \\
(14b) $\mathrm{CCl}_{2} \mathrm{O} \rightarrow \mathrm{Cl}_{2}+\mathrm{CO}$ & $7.60 \times 10^{-9}$ & 30549 & $1400-2000$ &
\end{tabular}

aSecond-order rate constants of the form, $\mathrm{k} /\left(\mathrm{cm}^{3}\right.$ molecule $\left.{ }^{-1} \mathrm{~s}^{-1}\right)=\mathrm{A} \exp (-\mathrm{B} / \mathrm{T})$. ${ }^{\mathrm{b}}$ First-order rate constants of the form, $\mathrm{k} / \mathrm{s}^{-1}=\mathrm{A} \exp (-\mathrm{B} / \mathrm{T})$. $\mathrm{B}$ and $\mathrm{T}$ both have units, $\mathrm{K}$.

modeling applications provided the density and temperature ranges are close to those used in the determinations. Note that the results are sometimes reported as either first- or second-order depending on the extent of unimolecular fall-off over the experimental temperature and pressure regimes. However, there is some degree of fall-off in all of the cases, and therefore, we have attempted to understand these results by performing unimolecular theoretical calculations. Troe and coworkers [28] have developed a methodology that is essentially a fit to the Rice-Ramsperger-Kassel-Marcus (RRKM) theory of unimolecular rate constants. This method has been applied to all of the present cases; however, we have also applied Gorin-model RRKM theory [16,27,29,30] and flexible 
transition state RRKM theory [16] to several of the cases. Regardless of which of the three methods is used, a transition state, including molecular parameters, must be identified using, at least, semiempirical and, sometimes, $a b$ initio electronic structure theory. In addition, knowledge of the molecular properties of the reactant molecule is also necessary. In general, the calculations of thermal rate constants then involve simultaneous parametric variation of the threshold energy, $\mathrm{E}_{0}$, and the average energy transferred per collision of the vibrationally excited molecule with bath gas, $\langle\Delta \mathrm{E}\rangle_{\text {down. }}$. In cases where the three methods have been applied, we have found that the final conclusions are not strongly dependent on the degree of theoretical rigor; i. e., the final mutual values for $\mathrm{E}_{0}$ and $\langle\Delta \mathrm{E}\rangle_{\text {down }}$ for a particular molecule does not depend strongly on which version of theory is used.

The theoretical results for the fourteen halo-organic molecules are summarized in Table 2 where the $\mathrm{E}_{0}$ and $\langle\Delta \mathrm{E}\rangle_{\text {down }}$ values that are necessary to explain the experimental data are presented along with $E_{0}$ 's from other experimental and theoretical sources. We can conclude that the threshold

Table 2.

Threshold Energy and Collisional Energy Transfer Parameter Values Obtained from Unimolecular Rate Theory Analysis of Dissociation Rate Data

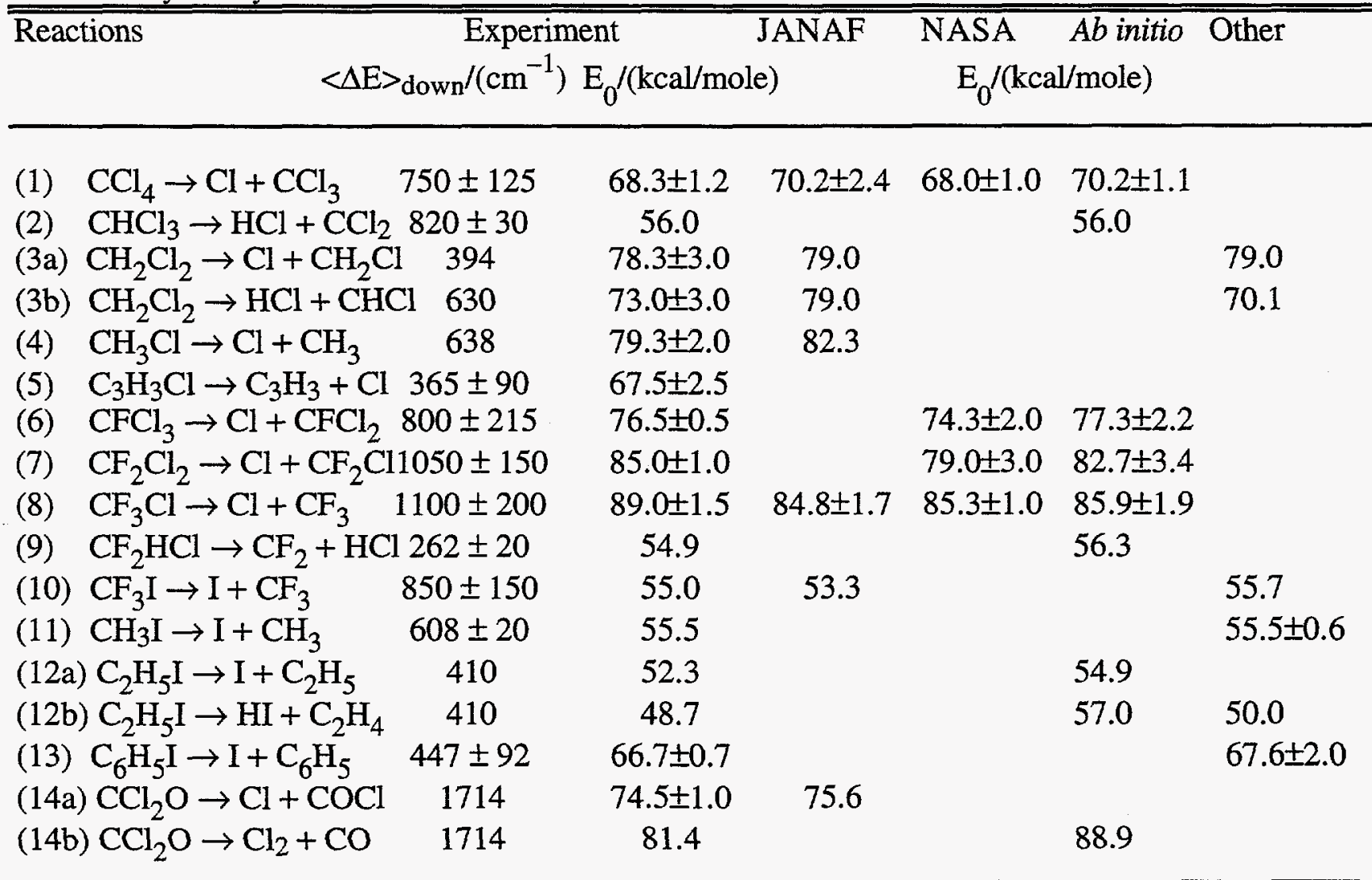

energies, determined from the present theoretical fits to the experimental rate data, agree with the other experimental and theoretical thermochemical values to within $\sim \pm 2 \mathrm{kcal} \mathrm{mole}^{-1}$. Hence, the present method is valuable for obtaining bond strengths within this accuracy range. Since the negative slope in Arrhenius plots is closely related to the threshold energy, this means that Arrhenius behavior is becoming better understood. However, the absolute magnitudes of the rate constants are largely dependent on the collisional deactivation efficiency, $\beta_{c}$, and this quantity is a function of $\langle\Delta \mathrm{E}\rangle_{\text {down }}$. We have noted that the implied values for $\langle\Delta \mathrm{E}\rangle_{\text {down }}$ in halogen containing molecules are quite large 
in comparison to hydrocarbon dissociations [31] and have suggested that this increased collision efficiency may be due to "mass matching" effects between the peripheral large halogen molecules and the relatively large bath gas molecules, Ar and/or $\mathrm{Kr}$ [15]. It is important to note that there is still no a priori theoretical chemical physics theory for $\beta_{\mathrm{c}}$ determination, and, until it can theoretically characterized, unimolecular rate theory will continue to be incomplete. Hence, $\beta_{\mathrm{c}}\left(<\Delta \mathrm{E}>_{\text {down }}\right)$ will have to be considered as an empirical parameter [32]. This means that purely theoretical predictions of rate behavior will not be sufficient. Experimental determinations will still be necessary.

Lastly, if destruction of halo-organic molecules by incineration if to be seriously considered, then we believe that it will be necessary to gain much more information before effluent emissions can be predicted or even rationalized. For example, in the some of these decompositions, $\mathrm{CCl}_{2}$ and/or $\mathrm{CF}_{2}$, singlet carbenes, are major decomposition products. The ultimate fate of these species will be dictated by the ratio of self recombination to bimolecular reaction with $\mathrm{O}_{2}$. The problem is that their are no accurate measurements of recombination rate constants, nor are there any rate constant determinations for carbene $+\mathrm{O}_{2}$, at incineration temperatures. Though recombination would probably give unsaturated $\mathrm{C}_{2}$ halocarbons, the products from carbene reaction with $\mathrm{O}_{2}$ are not clear. Even if the rate constants were known, there are still questions about what products would be formed, two of which could possibly be $\mathrm{CF}_{2} \mathrm{O}$ and $\mathrm{CCl}_{2} \mathrm{O}$. This example illustrates the severe lack of knowledge that presently has to be confronted before a chemical simulation for halo-organic molecular destruction can be attempted under incineration conditions.

\section{ACKNOWLEDGMENTS}

This work was supported by the U. S. Department of Energy, Office of Basic Energy Sciences, Division of Chemical Sciences, under Contract No.W-31-109-Eng-38.

\section{REFERENCES}

1 Montreal Protocol on Substances that Deplete the Ozone Layer, Final Act, UNEP, 1987; Revised, 1990, London Amendment.

2 Graham, J. L., Hall, D. L., Dellinger, B., Environ. Sci. Tech., 20, 703 (1986).

3 Oppelt, E. T., J. Air Poll. Contr. Assoc., 37, 558 (1987).

4 Yang, M., Karra, S. B., Senkan, S. M., Hazard. Waste Hazard. Mater., 4, 55 (1987).

5 Hart, J. R., Franco, G., Proceedings of the Third Symposium on the Incineration of Hazardous Wastes, San Diego, CA, 1989, Paper 15.

6 Michael, J. V., Prog. Energy Combust. Sci., 18, 327 (1992).

7 Michael J. V., In Advances in Chemical Kinetics and Dynamics, J. R. Barker, Ed., 1, 47 (1992), for original references.

8 Michael, J. V., Sutherland, J. W., Int. J. Chem. Kinet., 18, 409 (1986), 18, 409.

9 Michael, J. V., J. Chem. Phys., 90, 189 (1989).

10 Lim, K. P., Michael, J. V., J. Chem. Phys., 98, 3919 (1993).

11 Lim, K. P., Michael, J. V., 207th American Chemical Society, Fuel Chemistry Division, 39, 131 (1994). 
12 S. S. Kumaran, M.-C. Su, K. P. Lim, J. V. Michael, Chem. Phys. Lett., 243, 59 (1995).

13 Su, M.-C., Kumaran, S. S., Lim, K. P., Michael, J. V., Wagner, A. F., Dixon, D. A., Kiefer, J. H., DiFelice, J., J. Phys. Chem., 100, 15827 (1996).

14 Su, M.-C., Kumaran, S. S., Lim, K. P., Michael, J. V., Rev. Sci. Inst., 66, 4649 (1995).

15 Michael, J. V., Lim, K. P., Kumaran, S. S., Kiefer, J. H., J. Phys. Chem., 97, 1914 (1993).

16 Kumaran, S. S., Su, M.-C., Lim, K. P., Michael, J. V., Wagner, A. F., Harding, L. B., Dixon, D. A., J. Phys. Chem., 100, 7541 (1996).

17 Kumaran, S. S., Su, M.-C., Lim, K. P., Michael, J. V., Klippenstein, S. J., DiFelice, J., Mudipalli, P. S., Kiefer, J. H., Dixon, D. A., Peterson, K. A., J. Phys. Chem., submitted.

$18 \mathrm{Lim}, \mathrm{K}$. P., Michael, J. V., Twenty-Fifth Symp. (International) on Combustion; The Combustion Institute: Pittsburgh, 1994, p. 809.

19 Kumaran, S. S., Lim, K. P., Michael, J. V., Tilson, J. L., Suslensky, A., Lifshitz, A., Israel J. Chem., 36, 223 (1996).

20 Kumaran, S. S., Su, M.-C., Lim, K. P., Michael, J. V., Wagner, A. F., J. Phys. Chem., 100, 7533 (1996).

21 Kumaran, S. S., Lim, K. P., Michael, J. V., Wagner, A. F., J. Phys. Chem., 99, 8673 (1995).

22 Kiefer, J. H., Sathyanarayana, R., Lim, K. P., Michael, J. V., J. Phys. Chem., 98, 12278 (1994).

23 Kumaran, S. S., Su, M.-C., Michael, J. V., Int. J. Chem. Kinet., in press.

24 Kumaran, S. S., Su, M.-C., Lim, K. P., Michael, J. V., Twenty-Sixth Symp. (International) on Combustion, The Combustion Institute, Pittsburgh, 1996, p. 605.

25 Kumaran, S. S., Su, M.-C., Michael, J. V., Chem. Phys. Lett., in press.

26 Lim, K. P., Michael, J. V., J. Phys. Chem., 98, 211 (1994).

27 Kiefer, J. H., Manson, A. C., Rev. Sci. Inst., 52, 1392 (1981).

28 Troe, J., J. Chem. Phys., 66, 4745 (1977); ibid., 4758 (1977); Troe, J., J. Phys. Chem., 83, 114 (1979); Troe, J., Ber. Bunsenges. Phys. Chem., 87, 161 (1983); Gilbert, R. G., Luther, K., Troe, J., Ber. Bunsenges. Phys. Chem., 87, 169 (1983).

29 Benson, S. W., Golden, D. M., in Physical Chemistry, An Advanced Treatise,

Eyring, H.; Henderson, D.; Jost, W., Eds., Academic Press, New York, 1975, Vol. VII; Smith, G. P., Golden, D. M., Int. J. Chem. Kinet., 10, 489 (1978).

30 Smith, G. P., Manion, J. A., Rossi, M. J., Rodgers, A. S., Golden, D. M., Int. J. Chem. Kinet., 26, 211 (1994).

31 Tsang, W., Combust. Flame, 78, 71 (1989).

32 Michael, J. V., Lee, J. H., J. Phys. Chem., 83, 10 (1979); Michael, J. V., ibid. 17 (1979). 